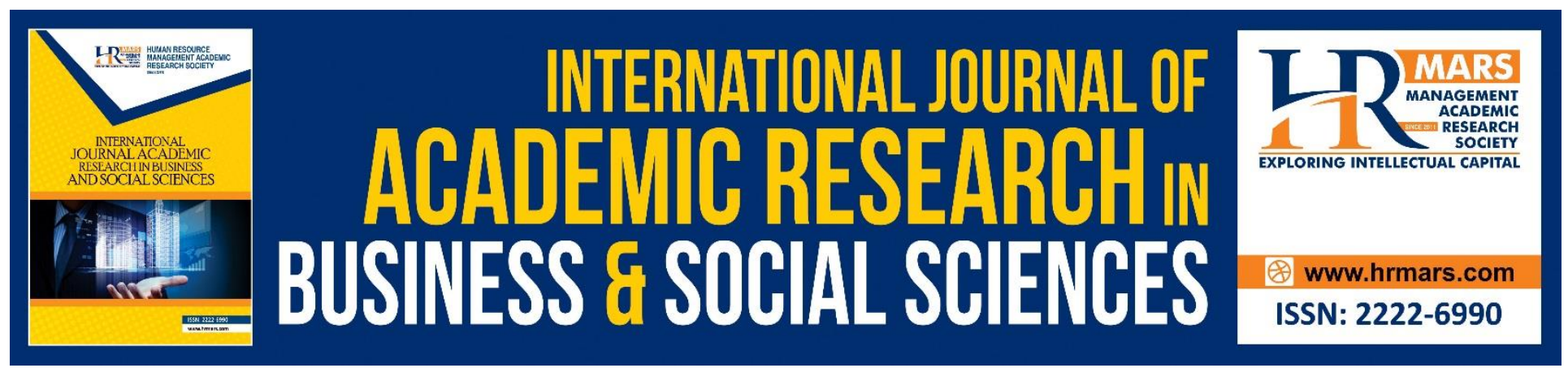

\title{
Product Quality Analysis on Pearly's Consumer Satisfaction
}

\author{
Charly Hongdiyanto
}

To Link this Article: http://dx.doi.org/10.6007/IJARBSS/v9-i3/5746

DOI: $\quad 10.6007 /$ IJARBSS/v9-i3/5746

Received: 14 Feb 2019, Revised: 17 March 2019, Accepted: 30 March 2019

Published Online: 07 April 2019

In-Text Citation: (Hongdiyanto, 2019)

To Cite this Article: Hongdiyanto, C. (2019). Product Quality Analysis on Pearly's Consumer Satisfaction. International Journal of Academic Research in Business and Social Sciences, 9(3), 800-808.

\section{Copyright: (c) 2019 The Author(s)}

Published by Human Resource Management Academic Research Society (www.hrmars.com)

This article is published under the Creative Commons Attribution (CC BY 4.0) license. Anyone may reproduce, distribute, translate and create derivative works of this article (for both commercial and non-commercial purposes), subject to full attribution to the original publication and authors. The full terms of this license may be seen at: http://creativecommons.org/licences/by/4.0/legalcode

Vol. 9, No. 3, 2019, Pg. 800 - 808

Full Terms \& Conditions of access and use can be found at http://hrmars.com/index.php/pages/detail/publication-ethics 


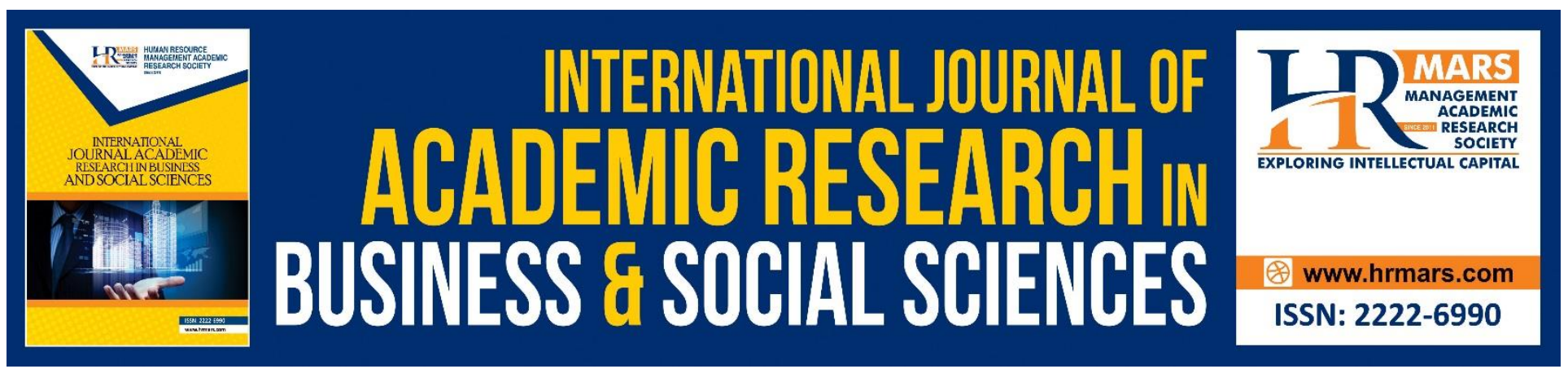

\title{
Product Quality Analysis on Pearly's Consumer Satisfaction
}

\author{
Charly Hongdiyanto
}

School of Management and Business, Ciputra University, UC Town, Citraland, Surabaya, Indonesia

\begin{abstract}
Pearly is a company engaged in jewelry industry, especially pearls. The purpose of this study is to describe what products the consumers want. The factors examined in this study were decided based on a preliminary survey that showed that product quality was the main factor influencing customer satisfaction. Data collection methods used in this study are observation and interview. The interview method used was semi-structured interviews with 5 people who had made purchases on Pearly's products. The data obtained is then analyzed using the data source triangulation method. The results of this study are to determine the management implications of the analysis result that has been obtained to improve product quality. The contribution of this study is related to the evidence-based practice as the result of qualitative research. Researcher able to find real comments about product quality from consumer perspective.
\end{abstract}

Keywords: Product Quality, Consumer Satisfaction, Pearl, Qualitative Research

\section{Introduction}

Indonesia's geographical factor which is flanked by two oceans and close to the equator causing Indonesia to have a warm tropical climate, so that many marine biota grow and develop in the Indonesian sea. One of the marine biota is pearl shell producing South Sea Pearl. South Sea Pearl is a pearl derived from pinctada maxima shell from both natural and cultured way. This type of pearl has the most brilliant luster and enduring color that is in great demand (Sutardjo, 2013). This type of pearl has the most brilliant and enduring color and luster. Pearls have been known for a long time as natural stones that have a luxurious luster and aura, so that they are widely used by nobles and royal queens as a symbol of wealth and elegance.

In Indonesia, pearls are not well known by the public because of the lack of promotion and support provided by the government. Pearl business began to develop since about 3 years ago, where the government began to pay attention and promote pearls through exhibition events and establish regional pearl exchanges, stated in Pos, (2013). Currently Indonesia controls $50 \%$ of the total world pearl production and its export value has touched 29 million US dollars. 
As the rapid development of fashion in the world, women increasingly pay attention to their appearance in everyday life or in signifying their social status. Jewelry is one of the fashion accessories favored by women to support their appearance. In the city of Surabaya, today jewelry is in great demand by the people. This is evidenced by the number of visitors who come and make buying and selling transactions during the jewelry exhibition event, as well as the increasing number of jewelry shops in the city of Surabaya. An exhibition that is regularly held annually, namely Jewelry Exhibition which takes place at the Shangri-La Surabaya hotel.

Pearly is a business engaged in jewelry, especially pearls. The purpose of the establishment of this business is to revive the elegant and luxurious value of pearls which are currently considered as ancient jewel for some young people. Pearly has custom products because Pearly wants customers to create their own creations and characteristics.

In this jewelry industry, there is a high competition between companies, so aspects such as product quality is very important and must always be considered because this affects the customer satisfaction and purchases. Based on this, the author has conducted an initial survey of several Pearly consumers regarding comments from products owned. Consumers are given the same question, what factors that make them satisfied or not satisfied with Pearly products that have been purchased. From consumer comments in the initial survey that has been conducted, it turns out that all consumers provide comments related to product quality. Based on this, the authors decided to do this research.

\section{Literature Review \\ Product Quality}

According to Kotler and Armstrong (2012), products are all things that are offered to the market to attract attention, acquisition, use or consumption that might meet needs and desires. Product quality is everything that is offered in a market to be considered, used, and consumed so as to meet and satisfy the desires or needs of consumers (Sunyoto, 2012). Hermawan (2011), also argued that product quality is the totality of features and characteristics that are able to satisfy needs, expressed and unstated, which include product durability, reliability, accuracy, ease of operation and repair, and other attributes values.

There are several good pearl qualification systems ("Pearl-Guide.com", 2018)

1. AAA: Best quality pearls, without spotting. Very sparkling and at least $95 \%$ of the surface is not deformed.

2. AA: Very shiny and $75 \%$ non-defective surface.

3. A: The lowest grade pearls jewelry, less luster and $>25 \%$ pearl surface is flawed.

4. Low Grade: Quality is not good, many spots and shapes are slightly oval.

Still in the same source ("Pearl-Guide.com", 2018), there are also several ways that can be done to find out the characteristics of quality pearls, namely:

1) Pearls must be stain free 
2) Not too rough or too smooth

3) The price of genuine pearls is more expensive than imitation

4) Genuine pearls are not flammable with fire (only burnt or black but not melted)

5) The bite feels like sandy but not scratched

In buying a jewelry product, usually someone will also pay attention to the quality of the binder. Here are some good jewelry quality specifications ("originalmutiara.com", 2018):

1) Gold

For gold with 22 carat content or $91 \%$ pure gold content, the color is shinier, not easily discolored, and not easily blackened.

2) Silver

Silver color does not fade quickly and does not easily change color, even if there is a color change, it relatively takes a long time

3) Rhodium

Not easy to change color and shiny frame color

4) Stainless

The color of the metal is shiny and does not easily change color

\section{Consumer Satisfaction}

The word 'satisfaction' comes from the Latin "satin" (meaning quite good, adequate) and "facio" (doing or making). In simple terms satisfaction can be interpreted as 'effort to fulfill something' or 'make something adequate'. Satisfaction is an important driver of consumer loyalty and many organizations or companies invest in programs to increase customer satisfaction (Hawkins \& Mothersbaught, 2010)

According to Hermawan (2011), consumer satisfaction is a response to consumer fulfillment of a consumption experience or a small part of that experience. Customer satisfaction must be a top priority where the level of interest and customer expectations and the implementation or performance of the company must be in accordance with customer expectations (Ridwan, 2012). There are three things that can be used to measure customer satisfaction according to Saidani and Samsul, (2012), namely:

1. Attributes related to product, related to the attributes of the product.

2. Attributes related to service, related to the attributes of the service.

3. Attributes related to purchase, relating to things that occur when consumers make a purchase and will make a repeat purchase.

Elements of customer satisfaction according to Tjiptono and Chandra (2011) are:

1. Quality goods and services

Companies that want to implement customer satisfaction programs must have good quality products and excellent services. Usually companies with high consumer satisfaction provide a high level of customer service.

2. Relationship Marketing 
The key to any promotional program is the effort to establish long-term relationships with customers. In other words, a strong and mutually beneficial relationship between service providers and customers can build a repeat business.

3. Loyalty promotion program

This program is widely applied to establish relationships between companies and customers. This program usually provides a kind of special award (such as bonuses, discounts and prizes that are associated with the frequency of purchases or use of company products / services) to customers.

4. Focus on the best customer Even though the loyalty program has a variety of forms, all of them have a commonality in terms of the most valuable consumer focus.

5. Effective complaints handling system

Complaint handling is closely related to product quality. The company must first ensure that the goods and services it produces actually function properly from the start. If there is a problem after that, the company immediately tries to fix it through a complaint handling system.

6. Unconditional guarantees

Unconditional guarantees are needed to support consumer satisfaction programs. Guarantee is an explicit promise delivered to consumers regarding the level of performance that they can expect to receive.

7. Program pay-for-performance

The consumer satisfaction program cannot be implemented without the support of organizational human resources. As the spearhead of companies that interact directly with consumers and are obliged to satisfy them, employees must also satisfy their needs.

Satisfaction occurs when the fulfillment of needs or expectations are achieved through interactions conducted by sellers and buyers (Tjiptono and Chandra, 2011). Bateson and Hoffman (2011) say that consumer satisfaction is obtained by comparing consumer expectation with consumer perception, and that the result they get is consumer expectation in accordance with consumer perception. From these definitions it can be concluded that customer satisfaction or dissatisfaction is a difference or gap between expectation before purchase and performance or perceived result after purchase.

\section{Research Methodology}

In this research, the author used a qualitative approach. Qualitative research is a scientific research that aims to understand a phenomenon in a social context naturally by prioritizing deep communication interaction process between researcher and the phenomenon studied (Herdiansyah, 2010). According to Moleong (2010), the subject of the study as an informant, which means people in the research background are used as a source of information needed in research data collection. In this study, the subject of five consumers of Pearly products were taken because they felt the influence of the quality of the products they bought. The criteria for consumers who will be used as research subjects are consumers who bought Pearly products for the first time and who did not make repeat purchases. 
Sanusi (2011) revealed that interviews are data collection techniques that use questions verbally to research subjects. Interviews conducted by researchers are personal interviews, where researchers conduct direct communication with respondents. Respondents who will be interviewed are consumers of Pearly products. The interview method used is a semi-structured interview where the researcher has prepared questions that will be submitted to the respondents.

To evaluate the validity of the study, triangulation method was used. Triangulation is a combination of various methods used to examine interrelated phenomena from different perspectives. Researcher use triangulation of data sources because they are considered most suitable when compared with other triangulation where data obtained from interviews will be compared with other respondents.

\section{Result and Discussion}

In this study, researcher used 5 Pearly consumers as research respondents. All respondents used were female and consisted of various types of jobs and ages. Consumer satisfaction is a response to consumer fulfilment of a consumption experience or a small part of that experience (Hermawan, 2011). Customer satisfaction must be a top priority where the level of interest and the implementation or performance of the company must be in accordance with customer expectation (Ridwan, 2012).

From the interview results, 4 out of 5 respondents indicated that they were not satisfied with Pearly's products. The statement also confirms that consumer satisfaction is obtained by comparing consumer expectation with consumer perception, and that the result they get is consumer expectation in accordance with consumer perception. The result of interviews with respondents indicate that the expectation is not in accordance with the perception, it can be concluded that consumers are not satisfied.

One respondent revealed that she was satisfied with the product from Pearly although there were some product attributes that had to be tidied up a bit. The opinion of the respondent shows that one of the factors that can measure consumer satisfaction is based on the attributes of the product itself (Saidai and Samsul, 2012). According to Tjiptono and Chandra (2011), there are seven elements of customer satisfaction, one of which is about quality goods and services.

The result of interviews with respondents shows that customer satisfaction must be a top priority and the satisfaction itself can be known and seen from the expectation is in accordance with the perception of consumers. Having good quality products is also a factor in customer satisfaction. Product quality is everything that is offered in a market to be considered, used, and consumed so as to meet and satisfy the desires or needs of consumers (Sunyoto, 2012). The conclusion obtained from the two respondents indicate that the quality or grade of pearls used by Pearly still includes low pearl quality, supported by statements from respondents who stated that there is still a defect and imperfect round shape of Pearly's pearls. Preliminary survey results that have been carried out earlier also indicate several consumer complaints regarding the quality of products from Pearly. 
Based on the result of interviews with all respondents, there were still many jewelry products from Pearly that needed improvement, such as the selection of pearl quality and also the use of binder types. Doing Quality Control and setting the standard of pearl quality that you want to use can be a solution to improve product quality in order to meet customer satisfaction.

Bateson and Hoffman (2011) said that customer satisfaction is obtained by comparing consumer expectation with consumer perception, and that the result they get is consumer expectation in accordance with consumer perception. Companies that want to implement customer satisfaction programs must have good quality products and excellent service (Hawkins and Mothersbaught, 2010). Quality product attributes are factors that influence customer satisfaction. Tjiptono defined that customer satisfaction is the customer's response to the perceived incompatibility between expectation and actual performance of the product in its use. Product attributes is one of the factors that increase customer loyalty, both directly and indirectly through satisfaction. All respondents stated that they were dissatisfied with the product from Pearly, this was due to a defect found on the surface of the pearl from Pearly. From the result of interviews with respondents, they said that they were not satisfied with the quality of the product or the quality of pearls from Pearly. It can be concluded that product quality is one of the important things that can affect customer satisfaction.

Based on the research that has been done, it was found that Pearly should do the standard setting on the quality of pearls to be used. Grade AA pearls and also grade AAA pearls are recommended to be used as the main ingredient of pearls in subsequent products. This is based on the result of interviews conducted by researcher with the respondents, and some of the respondents said that pearls are good and expected, namely pearls Grade AA and Grade AAA. Pearly can also make agreements with suppliers for the selection of pearls to be used.

Pearly will make plans for the next one-year program on products that will be supplied as well as products that will be produced to add to the collection. Pearly is expected in the future to be able to multiply products made from the binding of gold and rhodium. For binder types of copper, silver and monel, they will be reduced. This is based on the result of interviews with respondents who are consumers of Pearly products stating that the use of gold and rhodium is better because the two ingredients are not easily blackened and the color is more lustrous.

Based on the research that has been carried out, there are several criticisms regarding the final result of products with have defects. Pearly in the future will put more emphasis on the operational part in conducting Quality Control that will check the products coming from the supplier, if they have been inspected and there were no defects, the product can be distributed to consumers who order. To be able to better satisfy consumers, Pearly can contact consumers after the product is estimated to arrive to assure if there is no scratch. If there is a scratch when the product reaches the consumer, the consumer can send the product back and will be replaced with a new one 
INTERNATIONAL JOURNAL OF ACADEMIC RESEARCH IN BUSINESS AND SOCIAL SCIENCES

Vol. 9, No. 3, March, 2019, E-ISSN: 222 2-6990 ¿ 2019 HRMARS

\section{Conclusion}

This study aims to analyze how product quality affects consumer satisfaction in Pearly products, resulting in the following conclusions:

1. Product quality attributes affect customer satisfaction by comparing consumer's expectation with their experience in using the product. Majority of product attributes provided by Pearly is not satisfied enough from the point of view of the consumers.

2. The quality of products provided by Pearly is less satisfying to consumers. This conclusion is taken from all the respondent in which they all are giving bad comments towards Pearly's products.

Theoretical contribution from this research is to enhance the understanding of the concept of product quality and customer satisfaction. As for the contextual contribution that related to the actual experience, writer able to discover customer satisfaction from their point of view. This finding is beneficial for the writer and also the reader because sometimes what have written in the textbook about a certain concept is different with the actual real world. Knowing the concept and able to related it with real life experience is something urgent and advantageous.

In this study the price factor was not used by researcher as a factor of consideration. When the research was conducted, the consumer said that the quality of the product should be improved and there were price consequences that were not considered in this study. In the future research, other aspects that related to product quality should be used as the factors of consideration as well such; as price, service and variety of products. Other than that, quantitative research can also be used to find out relationship between customer satisfaction and product quality attributes.

\section{References}

Bateson, J. E. G. \& Hoffman, K. D. (2011). Services Marketing, 4th edition. South-Western Grading Pearls. (2018, October 16). Retrieved from http://www.pearl-guide.com/pearl-grading.shtml Hawkins, D. \& Mothersbaught, D. L. (2010). Consumer Behaviour: Building Marketing Strategy Eleventh Edition. New York: McGraw-Hill

Herdiansyah, H. (2010). Metodologi Penelitian Kualitatif. Jakarta. Salemba Humanika

Hermawan, B. (2011). Pengaruh Kualitas Produk terhadap Kepuasan, Reputasi Merek, dan Loyalitas Konsumen Jamu Tolak Angin PT. Sido Muncul. Jurnal Manajemen Teori dan Terapan, Vol. 4, (2), 9-17

Kotler, P. \& Armstrong, G. (2012). Principle of Marketing. $14^{\text {th }}$ Edition. New Jersey: Pearson Education Moleong, L. J. (2010). Metodologi Penelitian Kualitatif. Bandung: PT. Remaja Rosdakarya (edisi revisi) Ridwan, M. (2012). Analisis Kepuasan Konsumen Terhadap Aksesori Perak (Studi Kasus Nikeisha Silver). Jurnal Jurusan Manajemen Fakultas Ekonomi Universitas Jambi, Vol. 1 (2), 102-113

Saidai, B. and Samsul, A. (2012). Pengaruh Kualitas Produk \& Kualitas Layanan Terhadap Kepuasan Konsumen \& Minat Beli pada Ranch Market. Jurnal Riset Manajemen Sains Indonesia, Vol.3, (1), 1-22 
Sanusi, A. (2011). Metode Penelitian Bisnis. Jakarta: Salemba Empat

Sutardjo. I. M. \& Anurningsih. N. (2013). Indonesian South Sea Pearls. Jakarta, Afterhours Books Sunyoto, D. (2012). Dasar-dasar Manajemen Pemasaran. Yogyakarta: Buku Seru

Tips-Tips. (2018, September 29). Retrieved from http://originalmutiara.com/content/tips-artikel Tjiptono, F. \& Chandra, G. (2011). Service, Quality, and Satisfaction (3rd Edition). Jakarta: Andi 